\title{
Varicella zoster virus-induced neurological disease after COVID-19 vaccination: a retrospective monocentric study
}

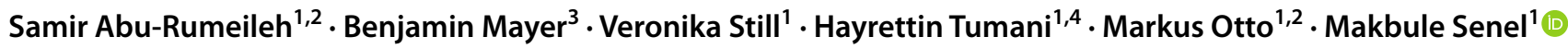

Received: 15 August 2021 / Revised: 12 October 2021 / Accepted: 13 October 2021 / Published online: 1 November 2021

(c) The Author(s) 2021

\begin{abstract}
The description of every possible adverse effect or event related to vaccines is mandatory during the ongoing worldwide COVID-19 vaccination program. Although cases of cutaneous varicella zoster virus (VZV) reactivation after COVID-19 vaccination have been increasingly reported in literature and database sets, a description of VZV-induced neurological disease (VZV-ND) is still lacking. In the present study, we retrospectively evaluated patients admitted to our clinic and diagnosed with VZV-ND during the COVID-19 vaccination campaign (January-April 2021) and in the same months in the previous two years. We identified three patients with VZV-ND after COVID-19 vaccination and 19 unvaccinated VZV-ND cases as controls. In the case-control analysis, the two groups showed no difference in clinical features, results of diagnostic investigations, and outcome. Thus, VZV reactivation with neurological involvement might be a possible event triggered by COVID-19 vaccination, but the benefit following COVID-19 vaccination overcomes significantly the potential risk associated with a VZV reactivation.
\end{abstract}

Keywords COVID-19 $\cdot$ SARS-CoV-2 $\cdot$ Varicella $\cdot$ Zoster $\cdot$ Vaccination $\cdot$ Vaccine

\section{Introduction}

To date, EMA approved in EU four vaccines against coronavirus disease 19 (COVID-19), namely Oxford/AstraZeneca chimpanzee adenovirus-vectored COVID-19 vaccine (ChAdOx1), Pfizer/BioNTech BNT162b2, Moderna mRNA1273, and Johnson \& Johnson/Janssen Ad26.COV2.S [1]. Despite the several benefits of vaccination in terms of public health, vigilance and safety monitoring of its side effects are mandatory. According to the Centers for Disease Control and Prevention (CDC) Vaccine Adverse Event Reporting System (VAERS) database, the most common adverse effects after COVID-19 vaccines are transient, including

Makbule Senel

makbule.senel@uni-ulm.de

1 Department of Neurology, University of Ulm, Ulm, Germany

2 Department of Neurology, Martin-Luther-University Halle-Wittenberg, Halle (Saale), Germany

3 Institute of Epidemiology and Medical Biometry, Ulm University, Ulm, Germany

4 Fachklinik für Neurologie Dietenbronn, Schwendi, Germany injection site pain, fever, and headache [2, 3]. Furthermore, cases of cutaneous varicella zoster virus (VZV) reactivation after COVID-19 vaccination have been reported in literature and database sets [2,5], but a definitive causal relationship is still to be confirmed.

VZV or Herpes zoster virus is a human neurotropic herpes virus. After primary infection (varicella), the virus becomes latent in neurons of cranial nerve ganglia or dorsal root ganglia [6-8]. Due to a decline in VZV cell-mediated immunity (e.g. age-related immunosenescence or immunosuppression) the virus may reactivate causing zoster and/or several neurological manifestations which may also develop without rash (sine herpete), such as cranial nerve palsies (e.g. Ramsay-Hunt syndrome), meningitis, encephalitis, (poly)radiculitis, cerebellitis, myelopathy, vasculopathy and postherpetic neuralgia [6-8]. Thus, the burden of VZV disease is relevant, with more than $90 \%$ of the world population harboring a latent virus and more than $50 \%$ with a reactivation by 85 years of age [8]. The diagnosis of VZVinduced neurological disease (VZV-ND) relies on the detection of VZV-DNA by PCR and/or intrathecal synthesis of anti-VZV IgG and IgM in the cerebrospinal fluid (CSF) [7]. The gold standard treatment is acyclovir. Among triggers for VZV reactivation, vaccines are rarely reported, but 
a vaccine-induced immunomodulatory mechanism might be potentially involved $[9,10]$. To date, there are cases of VZV reactivation concomitant with severe acute respiratory syndrome coronavirus type 2 (SARS-CoV-2) infection [11] but no description of VZV-ND after COVID-19 vaccination.

Taking into account all these issues, in the present study, we assessed the clinical features and results of diagnostic investigations of VZV-ND in a cohort of subjects during the COVID-19 vaccination campaign to evaluate a possible association between COVID-19 vaccination and VZV reactivation with neurological involvement.

\section{Methods}

\section{Subjects}

We performed a retrospective study at the Neurology Department of Ulm University Hospital (Germany). We identified all patients who were admitted to our clinic with a diagnosis of VZV-ND in the periods January-April 2021 (during COVID-19 vaccination), and we included a control groupwith the same diagnosis and recruited in the periods January-April 2019 and January-April 2020 (before COVID-19 vaccination). For the case-control analysis, we compared cases who received a vaccination against COVID19 within 6 weeks before clinical onset [12] and unvaccinated subjects (diagnosed in 2019, 2020 and 2021). The local ethics committee of the University of Ulm approved this study (ethics approval number 236/21).

\section{Diagnosis}

All cases with VZV-ND fulfilled the following criteria: (1) clinical picture of meningitis, encephalitis, meningoencephalitis, (poly) radiculitis, cerebellitis, myelitis, central nervous system (CNS) vasculopathy, (poly)neuritis cranialis and/or Ramsay-Hunt syndrome with or without zoster (sine herpete) [6-8], (2) complete CSF analysis including cell count and cell differentiation, $\mathrm{CSF} /$ serum albumin ratio, oligoclonal IgG bands (OCB), lactate, intrathecal IgG, IgA, and IgM synthesis, and confirmed VZV etiology by CSF PCR and/or increased pathogen-specific CSF/serum antibody indices (AIs) [6-8]; (3) available brain magnetic resonance imaging (MRI) at the day of lumbar puncture (LP) and (4) hospitalization with documented clinical history.

\section{Statistical analysis}

Statistical analysis was performed using IBM SPSS Statistics version 21 (IBM, Armonk, NY, USA). Due to the small sample size, descriptive results were generally expressed as the median and interquartile range (IQR) in the case of continuous variables, as well as absolute and relative frequencies otherwise. Statistical comparisons between COVID-19 vaccinated and unvaccinated VZV-ND cases were done using the Mann-Whitney U test and Fisher's exact test, whereas a $p<0.05$ was considered statistically significant in a fully explorative manner.

\section{Results}

In the periods January-April 2019, January-April 2020, and January-April 2021, we identified 6, 7, and 9 patients, respectively, with a diagnosis of VZV-ND who were admitted to our department. In the period January-April 2021, 3 cases received the COVID-19 vaccine before clinical onset, whereas 6 subjects were unvaccinated.

\section{Features of unvaccinated VZV-induced neurological disease cases (Table 1)}

The 19 unvaccinated VZV-ND subjects showed a prevalence of males (63\%) and a median age of 53 (IQR 39-71) years. The most common VZV-ND manifestations were meningitis $(n=12,63 \%)$ with $(n=4,21 \%)$ and without zoster (sine herpete) $(n=8,42 \%)$ and RamsayHunt syndrome $(n=4,22 \%)$. In all subjects, the CSF analysis revealed a lymphocytic pleocytosis (min 12-max $635 / \mu \mathrm{L}$ ) with increased protein levels. Increased lactate and CSF-blood-dysfunction were found in $42 \%$ and $74 \%$ cases, respectively. All cases showed no intrathecal Ig synthesis (in the Reiber diagrams for $\operatorname{IgM}, \operatorname{IgA}$, and $\mathrm{IgG}$ ), whereas $11 \%$ and $54 \%$ subjects had positive oligoclonal IgG bands at first and follow-up LP, respectively. A positive or borderline VZV-DNA-PCR was detected in $71 \%$ patients. In the follow-up LP, 85\% cases demonstrated an increased VZV-AI. CSF CXCL13 was elevated (>10 pg/ml) in 10 out of 12 tested patients. All cases were treated with acyclovir and showed a complete recovery or a clinical improvement.

\section{Features of vaccinated VZV-ND cases and comparison with unvaccinated subjects (Tables 2 and 3)}

All vaccinated VZV-ND cases showed neurological manifestations without zoster (sine herpete) (Table 2). A lymphocytic pleocytosis was disclosed in all patients. Protein levels were increased in $2 / 3$ patients. Lactate was within the normal range in $2 / 3$ patients. Oligoclonal $\operatorname{IgG}$ bands were positive in follow-up LPs in 2 out of 3 patients. VZV-PCR was positive in 1 out of 3 patients, whereas VZV-AI was 
Table 1 Features of unvaccinated VZV-induced neurological disease cases

\begin{tabular}{|c|c|}
\hline$N$ & 19 \\
\hline Age median (IQR); min-max & $53(39-71) ; 28-86$ \\
\hline Female $N(\%)$ & $7(36.84)$ \\
\hline \multicolumn{2}{|l|}{ Diagnosis $N(\%)$} \\
\hline Meningitis sine herpete (total) & $8(42.11)$ \\
\hline With CNS vasculopathy & $1(5.26)$ \\
\hline With (poly)neuritis cranialis & $2(10.53)$ \\
\hline Meningitis with zoster & $4(21.05)$ \\
\hline Meningoradiculitis sine herpete & $1(5.26)$ \\
\hline Encephalitis sine herpete & $1(5.26)$ \\
\hline Ramsay-Hunt syndrome with zoster & $3(21.05)$ \\
\hline Ramsay-Hunt syndrome sine herpete & $1(5.26)$ \\
\hline Trigeminal neuritis with zoster & $1(5.26)$ \\
\hline \multicolumn{2}{|l|}{ Main clinical features $N(\%)$} \\
\hline Headache and/or facial pain & $14(73.68)$ \\
\hline Facial palsy & $4(21.05)$ \\
\hline Hearing and/or vestibular impairment & $3(15.79)$ \\
\hline Other focal deficits & $3(15.79)$ \\
\hline Radicular pain & $2(10.53)$ \\
\hline Seizures & $3(15.79)$ \\
\hline Fever & $3(15.79)$ \\
\hline Nausea & $3(15.79)$ \\
\hline Zoster $N(\%)$ & $8(42.11)$ \\
\hline Previous COVID-19 & 1 case 1 year before \\
\hline \multicolumn{2}{|l|}{ Immunodeficit $\mathrm{N}(\%)$} \\
\hline Diabetes; IgA-deficit & $2(15.79) ; 1(10.53)$ \\
\hline \multicolumn{2}{|l|}{ Brain MRI } \\
\hline Normal; inflammatory changes or other alterations & $16(84.21) ; 3(15.79)$ \\
\hline \multicolumn{2}{|l|}{ EEG } \\
\hline Normal; abnormal & $6 / 7(85.71) ; 1 / 7(14.29)$ \\
\hline Time between onset and LP days Median (IQR) & $6(2-8)$ \\
\hline \multicolumn{2}{|l|}{ Leukocyte count $(/ \mu \mathrm{L})($ Norm $<5)$} \\
\hline Median (IQR); min-max & $176(60-453) ; 12-635$ \\
\hline Pleocytosis with $50-80 \%$ lymphocytes N (\%) & $9(47.37)$ \\
\hline Pleocytosis with $>80 \%$ lymphocytes $\mathrm{N}(\%)$ & $10(52.63)$ \\
\hline Protein (mg/L) (Normal range 200-500) Median (IQR) & $819(601-1845)$ \\
\hline Lactate (mmol/L) (Normal range 1.3-2.7) Median (IQR) & $2.41(1.95-3.20)$ \\
\hline Increased $N(\%)$ & $8(42.11)$ \\
\hline CSF/serum albumin ratio $\times 10-3$ Median (IQR) & $13.2(9.7-29.8)$ \\
\hline Blood-CSF-barrier dysfunction $N(\%)$ & $14(73.68)$ \\
\hline \multicolumn{2}{|l|}{ Positive oligoclonal IgG bands } \\
\hline In first LP N (\%); in follow-up LP $N(\%)$ & $2(10.53) ; 7 / 13(53.85)$ \\
\hline \multicolumn{2}{|l|}{ Intrathecal $\operatorname{IgG}, \operatorname{IgA}, \operatorname{IgM}$ synthesis } \\
\hline In the first LP N (\%); In the follow-up LP N (\%) & $0(0) ; 0(0)$ \\
\hline \multicolumn{2}{|l|}{ VZV-DNA-PCR in the first LPa } \\
\hline Positive; borderline $N(\%)$ & $10 / 17(58.82) ; 2 / 17(11.76)$ \\
\hline Negative $N(\%)$ & $5 / 17(29.41)$ \\
\hline \multicolumn{2}{|l|}{ VZV-AI > $1.5($ Normal < 1.5$)$} \\
\hline In the first LP N (\%); In the follow-up LP N (\%) & $7 / 16(43.75) ; 11 / 13(84.62)$ \\
\hline CXCL13 (pg/ml) $($ Normal < 10) Median $(\mathrm{IQR})$ & $50(10-240)$ \\
\hline Increased $N(\%)$ & $10 / 12(83.33)$ \\
\hline
\end{tabular}

AI antibody indices; COVID-19 coronavirus disease 19; CNS central nervous system; CSF cerebrospinal fluid; CXCL13 chemokine ligand 13; EEG electroencephalogram; IQR interquartile range; $L P$ lumbar puncture; $M R I$ magnetic resonance imaging; $P C R$ polymerase chain reaction; $V Z V$ varicella zoster virus ${ }^{a}$ In second LP when not performed in the first 
Table 2 Demographic, clinical characteristics and results of diagnostic investigations of vaccinated VZV-ND cases

\begin{tabular}{|c|c|c|c|}
\hline & Case 1 & Case 2 & Case 3 \\
\hline Age & 82 & 70 & 63 \\
\hline Sex & Female & Female & Male \\
\hline Diagnosis & $\begin{array}{l}\text { VZV meningitis with Ramsay-Hunt } \\
\text { syndrome sine herpete }\end{array}$ & VZV meningitis sine herpete & $\begin{array}{l}\text { VZV meningoradiculitis sine } \\
\text { herpete }\end{array}$ \\
\hline Clinical symptoms at admission & $\begin{array}{l}\text { Left peripheral facial palsy, } \\
\text { headache, facial pain, nausea and } \\
\text { vertigo }\end{array}$ & $\begin{array}{l}\text { Headache, left facial pain and } \\
\text { nausea }\end{array}$ & $\begin{array}{l}\text { Proximal pain in lower back and } \\
\text { lower limbs, headache }\end{array}$ \\
\hline Neurological examination & $\begin{array}{l}\text { Left peripheral facial palsy, left } \\
\text { vestibular defect }\end{array}$ & Unremarkable & Dysreflexia in the lower extremities \\
\hline Other clinical features & No typical skin, ear and eye lesions & No typical skin lesions & No typical skin lesions \\
\hline COVID-19 vaccine type & BNT162b2 & ChAdOx1 & ChAdOx1 \\
\hline Administration & 1st dose & 1st dose & 1st dose \\
\hline $\begin{array}{l}\text { Time between vaccination and } \\
\text { clinical onset (days) }\end{array}$ & 12 & 31 & 41 \\
\hline Serum SARS-CoV-2 IgA & NA & Negative & Negative \\
\hline Serum SARS-CoV-2 IgG & NA & Positive & Positive \\
\hline Previous varicella & In childhood & Not remembered & In childhood \\
\hline Previous zoster & No & No & No \\
\hline Previous zoster vaccination & No & No & No \\
\hline Previous COVID-19 & No & No & No \\
\hline Comorbidities & $\begin{array}{l}\text { Coronaropathy, hypertension, } \\
\text { dyslipidemia, obesity }\end{array}$ & None & None \\
\hline Brain MRI & Normal & $\begin{array}{l}\text { Normal (no signs of trigeminal } \\
\text { nerve involvement) }\end{array}$ & Normal \\
\hline Brain CT & No signs of sinusitis and otitis & NA & NA \\
\hline Spinal MRI & NA & NA & $\begin{array}{l}\text { Normal (no signs of radiculopathy, } \\
\text { myelopathy and lesions of conus/ } \\
\text { cauda equina) }\end{array}$ \\
\hline EEG & NA & Normal & Normal \\
\hline Routine blood investigations & Normal & Normal & Normal \\
\hline
\end{tabular}

COVID-19 coronavirus disease 19; CT computer tomography; EEG electroencephalogram; $M R I$ magnetic resonance imaging; NA not available; $S A R S-C o V-2$ severe acute respiratory syndrome coronavirus 2 ; $V Z V$ varicella zoster virus

increased in all patients. At variance with cases 2 and 3, in case 1 we did not detect a progressive increase of VZVAI between two consecutive LPs. Nevertheless, given the typical features of Ramsay-Hunt syndrome (e.g., facial and vestibulocochlear nerve involvement), a diagnosis of possible VZV-ND was made. All subjects showed variably high levels of CSF CXCL13 (Table 3). During the hospitalisation and under therapy with acyclovir, clinical picture and CSF biochemical parameters improved significantly in all patients. In detail, in patients 2 and 3 the symptoms completely disappeared, while in patient 1 we observed an improvement of facial palsy and vestibular defect, which further improved after rehabilitation.

All fully explorative comparisons revealed no statistically significant difference between vaccinated and non-vaccinated patients regarding demographic (age, sex, time from onset to LP), CSF parameters (leukocyte count, protein, lactate, $\mathrm{CSF} /$ serum albumin ratio, increased VZV-AI, positive
OCBs, positive/borderline VZV-DNA-PCR) and outcome. For MRI and EEG data, no comparison was possible due to the small sample size.

\section{Discussion}

A vigilant reporting and a complete transparency in the description of every possible adverse effect related to vaccines represent an important chapter in public healthcare during an ongoing worldwide vaccination program.

In the present study, we retrospectively evaluated patients who were admitted to our clinic and had a diagnosis of VZVND during the COVID-19 vaccination campaign (January-April 2021) and in the same months in the previous two years. We found three patients who developed VZV-ND after COVID-19 vaccination. Given that age is the major risk factor for VZV reactivation in $90 \%$ of cases [13] and that 
Table 3 CSF results of vaccinated VZV-ND cases

\begin{tabular}{|c|c|c|c|c|c|c|c|}
\hline \multirow[t]{2}{*}{ LP } & \multicolumn{2}{|l|}{ Case 1} & \multicolumn{2}{|l|}{ Case 2} & \multicolumn{3}{|l|}{ Case 3} \\
\hline & first & second & first & second & first & second & third \\
\hline $\begin{array}{l}\text { Days from clinical } \\
\text { onset }\end{array}$ & 7 & 17 & 5 & 9 & 5 & 11 & 17 \\
\hline $\begin{array}{l}\text { Leukocyte count }(/ \mu \mathrm{L}) \\
(<5)\end{array}$ & 325 & 46 & 34 & 63 & 1124 & 341 & 111 \\
\hline Lymphocytes (\%) & 70 & 75 & 88 & 85 & NA & 70 & 67 \\
\hline $\begin{array}{l}\text { Activated lymphocytes } \\
(\%)\end{array}$ & 15 & 9 & 8 & 7 & NA & 19 & 9 \\
\hline Plasmacells (\%) & 6 & 0 & 2 & 1 & NA & 5 & 3 \\
\hline Monocytes (\%) & 9 & 14 & 2 & 7 & NA & 6 & 11 \\
\hline $\begin{array}{l}\text { Protein }(\mathrm{mg} / \mathrm{L}) \\
\text { (Normal range } \\
200-500)\end{array}$ & 1256 & 985 & 415 & 382 & 1635 & 546 & 509 \\
\hline $\begin{array}{l}\text { Lactate }(\mathrm{mmol} / \mathrm{L}) \\
\text { (Normal range } 1.3-2.7 \text { ) }\end{array}$ & 3.79 & 3.27 & 1.5 & 1.46 & 2.62 & 2.15 & 1.91 \\
\hline $\begin{array}{l}\mathrm{CSF} / \text { serum albumin } \\
\text { ratio } \times 10^{-3}\end{array}$ & 17.7 & 14.6 & 5.3 & 5.2 & 22.7 & 9.5 & 7.2 \\
\hline $\begin{array}{l}\text { Blood-CSF-barrier } \\
\text { dysfunction }\end{array}$ & Yes & Yes & No & No & Yes & Yes & NA \\
\hline oligoclonal IgG Bands & Negative & Positive & Negative & Negative & Negative & Positive & NA \\
\hline $\begin{array}{l}\text { Intrathecal } \operatorname{IgG}, \operatorname{Ig} \mathrm{A}, \\
\text { IgM synthesis }\end{array}$ & No & $\operatorname{IgA} 20.2 \%$ & No & No & No & No & No \\
\hline VZV-DNA-PCR & NA & Negative & NA & Negative & Positive & Borderline & Negative \\
\hline $\begin{array}{l}\text { VZV-AI } \\
(\text { Normal < } 1.5)\end{array}$ & 8.0 & 4.2 & 0.9 & 5.2 & 1.3 & 2.6 & NA \\
\hline $\begin{array}{l}\text { CXCL13 }(\mathrm{pg} / \mathrm{ml}) \\
(\text { Normal < } 10)\end{array}$ & 366 & 45 & NA & 18 & 63 & 45 & NA \\
\hline CSF SARS-CoV2-PCR & NA & Negative & NA & Negative & Negative & NA & NA \\
\hline $\begin{array}{l}\text { CSF SARS-CoV-IgA } \\
\text { and IgG }\end{array}$ & NA & NA & NA & Negative & Negative & NA & NA \\
\hline $\begin{array}{l}\text { Investigations with } \\
\text { normal results }\end{array}$ & $\begin{array}{l}\text { HSV } 1,2 \text {, bacteria, fungi } \\
\text { b., TBE }\end{array}$ & gi, Borrelia & $\begin{array}{l}\text { HSV 1,2, CMV, EBV, HH } \\
\text { bacteria, fungi, Borrelia } \\
\text { TBE, Mumps, Rubella, } \\
\text { HAV, HBV, HCV, tuber } \\
\text { CNS-autoantibodies, au } \\
\text { mune screening }\end{array}$ & $\begin{array}{l}\text { HV6, } \\
\text { a b., } \\
\text { HIV, } \\
\text { rcolosis, } \\
\text { utoim- }\end{array}$ & $\begin{array}{r}\text { HSV 1,2, } \\
\text { fungi, B }\end{array}$ & HV6, bacteri & \\
\hline
\end{tabular}

$A I$ antibody indice; $C M V$ cytomegalovirus; $C S F$ cerebrospinal fluid; $C X C L 13$ Chemokine ligand $13 ; E B V$ Epstein-Barr virus; $H A V, H B V, H C V$ hepatitis A, B, C virus; HHV6 human herpesvirus 6; HIV human immunodeficiency virus; $H S V$ herpes simplex virus; $L P$ lumbar puncture; $M R I$ magnetic resonance imaging; $N A$ not available; $P C R$ polymerase chain reaction; $S A R S-C o V-2$ severe acute respiratory syndrome coronavirus 2 ; $T B E$ Tick-borne encephalitis; $V Z V$ varicella zoster virus

none of our cases was immunosuppressed, one could argue that age might have played here a significant role. However, demographic features, including age, outcome, and results of a diagnostic investigation, did not differ between vaccinated and unvaccinated VZV-ND cases. From one side, this finding may suggest that the vaccine could have triggered or at least contributed to the virus reactivation. On the other side, the typical good outcome in most VZV-ND cases and the low case fatality [14] seem to characterise also VZV-ND after COVID-19 vaccination.
The BNT162b2 and ChAdOx1vaccine trials reported no cases of zoster or VZV-ND as adverse events among vaccine recipients [15-17]. Moreover, a recent study found no evidence for increased oropharyngeal reactivation of herpesviruses one week after BNT162b2 administration, arguing against a possible reactivation mechanism linked to the vaccination [18]. However, besides the short observation period (e.g., 1 week), the authors did not exclude that a symptomatic reactivation in trigeminal ganglion, facial nerve, or skin, might possibly occur with no increased oropharyngeal shedding [18]. Conversely, in 
both CDC VAERS and in the Yellow Card adverse reaction reporting scheme of Medicines and Healthcare products Regulatory Agency (MHRA) large databases sets, VZVrelated complications after BNT162b2 and ChAdOx1 vaccines are increasingly observed $[2,4]$. Accordingly, a very large epidemiological study showed that BNT162b2 vaccination was strongly associated with herpes zoster virus infection (e.g., VZV reactivation) with a risk ratio of 1.43 and a risk difference of 15.8 events per 100,000 persons at 6 weeks after administration [19]. Therefore, we would speculate that vaccines, including those against COVID19 , may induce an immunomodulatory effect with a temporary failure of $\mathrm{VZV}$-specific T-cell response leading to VZV reactivation [10]. In this regard, several data support the role of T-cell-mediated immunity for the maintenance of latency of VZV [10, 20].

Given the monocentric nature and the small sample size of the study, we were not able to assess the possible association between COVID-19 vaccination and VZV-ND. Furthermore, based on the available data, it did not seem reasonable to calculate valid estimates for the incidence of VZV-ND in vaccinated and unvaccinated patients. In particular, an appropriate definition of the denominator is tough considering the current dynamic situation of COVID-19 vaccination rates. On another issue, one could argue that the first COVID-19 outbreak may have partially influenced the prevalence of VZV-ND observed in 2020, given the reported significant decrease in hospital admissions for neurological disorders (e.g., for stroke [21]). However, in 2019 (before the pandemic), a similar number of VZV-ND patients was admitted to our department. Nevertheless, we could not exclude that the temporal association between VZV reactivation and vaccination might represent only a pure coincidence. In this regard, we are aware that future epidemiological studies with longer follow-up periods may confirm or question the association between COVID-19 vaccination and VZV reactivation.

However, our data, together with concomitant observations, suggest that VZV reactivation might be a possible rare event triggered by COVID-19 vaccination and should aware clinicians to promptly consider this manifestation in the differential diagnosis and to rapidly start the specific antiviral treatment. Nevertheless, considering the morbidity and mortality associated with COVID-19, the benefit following COVID-19 vaccination overcomes significantly the potential risk associated with a VZV reactivation. However, in view of the hundreds of millions of individuals to be vaccinated against SARS-CoV-2, larger epidemiological studies are needed to definitely elucidate all these issues.

Acknowledgements We are indebted to the staff of the CSF Lab Ulm.
Author contributions Conception and design of the study: SAR, BM and MS; acquisition and analysis of data: SAR, BM, VS, HT, MO, MS; drafting of the manuscript: SAR, BM and MS.

Funding Open Access funding enabled and organized by Projekt DEAL. MO received funding from the State Baden-Wuerttemberg (COVID-funds).

Data availability Not applicable.

Code availability Not applicable.

\section{Declarations}

Conflicts of interest The authors declare that they have no conflict of interest.

Ethical approval The local ethics committee of the University of Ulm approved this study (ethics approval number 236/21).

Open Access This article is licensed under a Creative Commons Attribution 4.0 International License, which permits use, sharing, adaptation, distribution and reproduction in any medium or format, as long as you give appropriate credit to the original author(s) and the source, provide a link to the Creative Commons licence, and indicate if changes were made. The images or other third party material in this article are included in the article's Creative Commons licence, unless indicated otherwise in a credit line to the material. If material is not included in the article's Creative Commons licence and your intended use is not permitted by statutory regulation or exceeds the permitted use, you will need to obtain permission directly from the copyright holder. To view a copy of this licence, visit http://creativecommons.org/licenses/by/4.0/.

\section{References}

1. https://www.ema.europa.eu/en/human-regulatory/overview/public-health-threats/coronavirus-disease-covid-19/treatments-vacci nes/vaccines-covid-19/covid-19-vaccines-authorised\#authorisedcovid-19-vaccines-section

2. https://vaers.hhs.gov/data.html

3. Goss AL, Samudralwar RD, Das RR, Nath A (2021) ANA investigates: neurological complications of COVID-19 vaccines. Ann Neurol 89:856-857. https://doi.org/10.1002/ana.26065

4. https://www.gov.uk/government/publications/coronavirus-covid19-vaccine-adverse-reactions

5. Català A, Muñoz-Santos C, Galván-Casas C et al (2021) Cutaneous reactions after SARS-COV-2 vaccination: a cross-sectional Spanish nationwide study of 405 cases. Br J Dermatol. https:// doi.org/10.1111/bjd.20639

6. Gilden D, Nagel MA, Cohrs RJ (2014) Varicella-zoster. Handb Clin Neurol 123:265-283. https://doi.org/10.1016/B978-0-44453488-0.00012-2

7. Nagel MA, Gilden D (2014) Neurological complications of varicella zoster virus reactivation. Curr Opin Neurol 27:356-360. https://doi.org/10.1097/WCO.0000000000000092

8. Nagel MA, Niemeyer CS, Bubak AN (2020) Central nervous system infections produced by varicella zoster virus. Curr Opin Infect Dis 33:273-278. https://doi.org/10.1097/QCO.0000000000 000647 
9. Walter R, Hartmann K, Fleisch F et al (1999) Reactivation of herpesvirus infections after vaccinations? Lancet 353(9155):810. https://doi.org/10.1016/S0140-6736(99)00623-6

10. Psichogiou M, Samarkos M, Mikos N, Hatzakis A (2021) Reactivation of varicella zoster virus after vaccination for SARS-CoV-2. Vaccines (Basel) 9(6):572. https://doi.org/10.3390/vaccines90 60572

11. Diez-Domingo J, Parikh R, Bhavsar AB et al (2021) Can COVID19 increase the risk of herpes zoster? A narrative review. Dermatol Ther (Heidelb). https://doi.org/10.1007/s13555-021-00549-1

12. Furer V, Zisman D, Kibari A et al (2021) Herpes zoster following BNT162b2 mRNA Covid-19 vaccination in patients with autoimmune inflammatory rheumatic diseases: a case series. Rheumatology (Oxford). https://doi.org/10.1093/rheumatology/keab345

13. Johnson RW, Alvarez-Pasquin MJ, Bijl M et al (2015) Herpes zoster epidemiology, management, and disease and economic burden in Europe: a multidisciplinary perspective. Ther Adv Vaccines 3:109-120. https://doi.org/10.1177/2051013615599151

14. Tseng HF, Bruxvoort K, Ackerson B et al (2020) The epidemiology of herpes zoster in immunocompetent, unvaccinated adults $\geq 50$ years old: incidence, complications, hospitalization, mortality, and recurrence. J Infect Dis 222:798-806. https://doi.org/10. 1093/infdis/jiz652

15. Polack FP, Thomas SJ, Kitchin N et al (2020) Safety and efficacy of the BNT162b2 mRNA Covid-19 vaccine. N Engl J Med 383:2603-2615. https://doi.org/10.1056/NEJMoa2034577
16. Baden LR, El Sahly HM, Essink B et al (2021) Efficacy and safety of the mRNA-1273 SARS-CoV-2 vaccine. N Engl J Med 384:403-416. https://doi.org/10.1056/NEJMoa2035389

17. Voysey M, Clemens SAC, Madhi SA et al (2021) Safety and efficacy of the ChAdOx1 nCoV-19 vaccine (AZD1222) against SARS-CoV-2: an interim analysis of four randomised controlled trials in Brazil, South Africa, and the UK. Lancet 397:99-111. https://doi.org/10.1016/S0140-6736(20)32661-1

18. Brosh-Nissimov T, Sorek N, Yeshayahu M et al (2021) (2021) Oropharyngeal shedding of herpesviruses before and after BNT162b2 mRNA vaccination against COVID-19. Vaccine 39(40):5729-5731. https://doi.org/10.1016/j.vaccine.2021.08.088

19. Barda N, Dagan N, Ben-Shlomo Y et al (2021) Safety of the BNT162b2 mRNA Covid-19 vaccine in a nationwide setting. N Engl J Med 385:1078-1090

20. Gnann JW Jr, Whitley RJ (2002) Clinical practice. Herpes zoster. N Engl J Med 347:340-346. https://doi.org/10.1056/NEJMcp0132 11

21. Sacco S, Ricci S, Ornello R et al (2020) Reduced admissions for cerebrovascular events during COVID-19 outbreak in Italy. Stroke 51:3746-3750. https://doi.org/10.1161/STROKEAHA.120. 031293 